\title{
Students' Attitudes and Beliefs Regarding the Use of E-Portfolio as an Alternative Form of Assessment: Results from a Pilot Survey in Greek Primary Education
}

\author{
Vasiliki Zafiropoulou ${ }^{1} \&$ Maria Darra ${ }^{1, *}$ \\ ${ }^{1}$ Med Education Sciences, University of Aegean, Rhodes, Greece \\ *Corresponding author: Med Education Sciences, University of Aegean, Dimokratias 1, 7th \\ March Building, 85100, Rhodes, Greece. Tel: 30-693-242-5804. E-mail: darra@aegean.gr
}

Received: February 16, 2019 Accepted: March 11, 2019 Published: March 20, 2019

doi:10.5296/ije.v11i1.14350 URL: https://doi.org/10.5296/ije.v11i1.14350

\begin{abstract}
The purpose of this paper is to investigate the contribution of the eportfolio to the development of positive attitudes and beliefs of students towards school and learning, as well as to the acquisition of self-assessment skills by students. The method used is the experiment using an experimental and a control group and two pre and post measurements. The survey was carried out during the first trimester of the school year 2016-2017 and a sample of 40 pupils of the second grade of the elementary school in the city of Rhodes. The findings of the survey show that students of both groups after the end of the intervention have a more positive attitude towards school and learning, but the experimental group that utilized the eportfolio has even higher rates of positive responses. In addition, in relation to the contribution of the eportfolio to the development of self-assessment skills by students, the students of the e-portfolio experimental group evaluated their performance higher than their teacher's assessment.
\end{abstract}

Keywords: E- portfolio, Authentic assessment, Student assessment, Student self-assessment 


\section{Introduction}

Educational assessment is taking an upgraded social and pedagogical role in the learning society today. It is called "assessment for learning" or "assessment as a learning tool". Electronic Student Portfolio (e-portfolio), the digital version of the traditional portfolio, is a new approach to authentic assessment (Barrett \& Knezek, 2003; Beresford, \& Cobham., 2011) which is based on ICT and falls on the category of alternative forms of assessment (Barrett, 2000; Papathanasiou \& Manousou, 2011).

Several researches have been carried out regarding the e-portfolio, both in theoretical approaches and in practical applications at all levels of education. There are many institutions and organizations around the globe (EIfEL, BECTA, AAC \& U, MOSEP, AAEBL, e-portfolios, e-portfolio California, e-portfolio Australia) working with the e-portfolio and its implementation by conducting numerous studies in cooperation with researchers (Ritzhaupt, Singh, \& Seyferth, 2008), universities, colleges and schools at all levels of education (Hallam, \& Creagh, 2010; Klampfer, \& Köhler, 2013; Hsieh, \& Chen, 2015). Their majority concerns higher education and the practical application of the e-portfolio to college and university students (Knight, Hakel, \& Gromko, 2006; Coutinho \& Bottentuit, 2008; McWhorter, Delello, Roberts, Raisor, \& Fowler, 2013; Nor Azlan, Amin, \& Mohd, 2015).

There are also surveys that concern teachers (Coutinho \& Bottentuit, 2008). In the Greek educational reality, the surveys carried out are smaller in number and limited in range. More specifically, these surveys focus on the theoretical approach of e-portfolio and software as well as applications for e-portfolio development (Stylianou, 2013). There are also researches that record the beliefs and attitudes of educators (Paroutsas, 2011), and primary school students regarding the application of the traditional portfolio (Tsoutstou \& Bertsou, 2013), as well as surveys conducted to students of primary education where e-portfolio was applied, but also to students of secondary education (Papathanasiou \& Manousou, 2011). Finally, there are researches concerning both teachers of primary education and teachers of secondary education (Fotopoulou, 2012). In Greece, the studies about the use of the e-portfolio in the educational process through classroom activities are scarce. There is, therefore, a limited amount of research on the incorporation of the e-portfolio in the educational process in Greece, which also doesn't revolve around language courses.

This survey has been carried out aiming to fill this gap and specifically to explore the contribution of the electronic portfolio (e-portfolio), in the teaching of the course of Greek language in the second class of primary school. Specifically, the study aims to investigate the contribution of e-portfolio in shaping more positive attitudes of students towards school and learning, as well as on the acquisition of self-assessment skills by students. The results given throughout its course will highlight an alternative aspect of the use of technology in the educational process. Hopefully, it will encourage researchers to explore its further use in other teaching subjects and inform teachers about new possibilities of technology in education so as to be motivated to optimize it. 


\section{Theoretical Framework}

Authentic assessment is an alternative form of assessment, which integrates the assessment of traditional academic content with the knowledge and skills that are important for lifelong learning, using a variety of techniques, including simulations of real-world situations. It's incorporated into the educational process and it's scientifically based on the theory of social constructivism (Vygotsky, 1978 in Rekalidou, Zantali, \& Sofianidou, 2010), as it creates a constructive alignment between teaching, learning and evaluating. It includes multiple forms of performance measurement, reflecting the student's acquisition of knowledge, as well as the achievements, motives and behaviors that are developed during the implementation of the activities (Callison, 1998; Wuetherick, B. \& Dickinson, J., 2015; Landis, Scott, \& Kahn, 2015; Mason, \& Williams, 2016). Its main requirement is authentic teaching as well as authentic learning (Varsamidou \& Res, 2007; Parker, Ndoye, \& Ritzhaupt, 2012)). To sum up, authentic assessment presupposes authentic teaching, followed by the assessment of learning. Students construct their new knowledge on what they have already acquired, based on individual and collective experiences. This results to the promotion of a holistic perception of the world through experiential situations and ensures the student's ability to act, shape and self-assess (Hendrickson, 2012).

The e-portfolio is an alternative form - method of assessment for students. Contrary to the more restrictive traditional methods, the main objective of alternative assessment formats is a multi-facetted evaluation of students' attitudes, opinions and performance. They are authentic techniques, implemented in activities, which help students meet every day, real life situations (Paris \& Ayres, 1994) by encouraging reflection and self-assessment contributing to the development of social and metacognitive abilities (Segers, 1999). Alternative assessment has the potential to reverse the traditional pattern of students' passivity, replacing it with initiative, self-discipline and choice (Meyer, 1992). Alternative assessment is a type of formative assessment, a continual process. It does not substitute other types of evaluation, but it can be applied alongside them, helping to better capture pupils' attitudes and performance (Tsagari, 2011). The main alternative forms of assessment are (Brown, 1998): a) authentic assessment b) self-assessment c) portfolio-e-portfolio and d) descriptive assessment. Among others, many writers refer to methods (not in forms of alternative assessment) such as (Tsagari, 2011): calendars, group projects, external evaluation, systematic observation, dramatization, storytelling, consultative meetings, exchange of opinions.

\section{Main Purpose and Research Questions}

The main purpose of this paper, which is part of a wider research effort, is to explore the use of the e-portfolio as an alternative form of teaching and authentic assessment of learning in primary education. In particular, the paper aims to investigate to what extent can the e-portfolio contribute to: a) the development of more positive attitudes of pupils towards learning, b) the development of more positive attitudes of students towards school, classroom/ in-class environment and school life in general and c) the development of students' self-assessment skills. 


\section{Al Macrothink}

The research questions this paper will attempt to answer are the following:

1: To what extent does the e-portfolio contribute to the development of students' positive attitudes towards learning in relation to the traditional printed portfolio?

2: To what extent can the e-portfolio contribute the in the shaping of more positive attitudes of students towards school, the classroom and school life in general in relation to the traditional portfolio?

3: To what extent does the e-portfolio contribute to the development of students' self-assessment skills?

\section{Method-Sample}

The sample selected for the experiment consisted of forty (40) students of the second class of the 1st Experimental Primary School in the city of Rhodes. The sample is equivalent in gender and number, as the participants are twenty boys $(50 \%)$ and twenty girls $(50 \%)$ between 7 and 8 years old.

The method used was the quasi-experiment using an experimental group and a control group. The survey was conducted during the first trimester of the school year 2016-2017, and in particular from 19 September 2016 until 9 December 2016. The e-portfolio was incorporated in the teaching and evaluation of the Greek language course in the second grade of primary school. The 40 subjects formed two groups of twenty people. Group A was the experimental group, in which the students used the electronic portfolio (e-portfolio) and group B was the control group, in which students used the traditional printed portfolio.

As far as data collection tools, we used:

The Pre-Questionnaire, a questionnaire regarding students' attitudes towards learning and school life.

The Post-Questionnaire, a questionnaire on how students' attitudes towards learning and school life have been shaped after the experiment was conducted.

Separate Self-Assessment Tables - Rubrics for each unit of the Language Course.

The questionnaires that were used as a research tool in this study are modified versions of existing relevant questionnaires found on the following websites: National Center for School Engagement, The Vermont Department of education's official web site, Cengage Learning, CESNational, and The Texas Center for Educational Technology.

These questionnaires are an effort to find out whether there is a change in the way students perceive and engage school life. Research on student attitudes towards school and learning should include three types of engagement:

Behavioral engagement

Cognitive engagement 
Emotional engagement

Behavioral engagement involves dealing with school work and refers to factors such as effort, persistence, participation and concentration, and refers to compliance with the rules.

Cognitive engagement is related to the psychological commitment to learning, and indicators such as problem-solving ability and intellectual effort are examined.

Emotional commitment includes interests and feelings associated with attitudes towards teachers and classmates, as well as the feeling of involvement in the group.

In the questionnaires there are proposals covering all three categories.

\section{Data Collection and Analysis}

Microsoft Excel spreadsheet software and SPSS statistics 21.0 were used to process data and generate results.

Eight (8) assessment rubrics were completed by both the students and the teachers to draw conclusions about the development of students ' self-assessment skills. Also, a questionnaire was filled out twice, before and after the completion of the program, in order to assess the students' attitudes towards learning, school, the classroom and school life in general.

In order to compare the rubrics' results of students and teachers we created an equal number of variables for each measurement table, the values of which are based on the recorded statements, grading with one [1] [Good], two [2] [Very Good] and with three [3] [Excellent].

Accordingly, for the comparison of the questionnaires, we created two indicators, one for each group of likert type questions, summing up the values of the respective questions in the group, where the statement [completely disagree] corresponds to [1], the statement [I disagree] with [2], [I don't know] [3], the statement [I agree] with [4] and finally [I completely agree] with [5].

The research data analysis was carried out on two levels, initially with the descriptive analysis and then with the inductive analysis. At the stage of descriptive statistical analysis, frequency distribution tables are given for the case of nominal variables. For quantitative variables the statistical, $m$ average score was used to measure central tendency and the standard deviation as a dispersion measure. On the same stage, there was also conducted a control of regularity with the statistical criterion Shapiro-Wilks (sample $<50$ persons), to decide the use of the statistical criterion for checking the statistical significance of the differences, depending on the existence or not of normal distribution.

At the stage of inductive statistics, the following statistical criteria were applied depending on the case and the stage of experimental research (Andreadakis, 2006).

Comparison of rubric statements- values: 


\section{Macrothink}

The statements of students and teachers were audited in order to compare and evaluate the quality of self-assessment, where the independent variable is a categorical variable with two positions (Control Group and Experimental Group) and the dependent variables are quantitative. The t-test criterion was applied for independent samples, in cases where the distribution is normal and the Mann-Witney criterion for the rest of them.

Comparison of questionnaire statements:

During the initial verification of equivalence, in which we checked the indicator values in both likerts of the Experimental and Control group students, where the independent variable is a categorical variable with two positions (Control Group and Experimental Group) and the dependent variables are quantitative variables, we applied the t-test criterion for independent samples in the first case because the distribution is normal and the Mann-Witney criterion in the second case, as values did not follow the normal distribution.

\section{Research Process}

The e-portfolio was used in the context of the evaluation of the Greek Language course in the Second Grade of Primary School. The participants were students of the 1st Experimental Primary School of Rhodes, in which the researcher has an established post and has been working there the last 6 years. Both classes of the school's second grade participated in the survey. The experimental group consisted of the B2 class students, where the researcher is teaching and B1 class students were the control group.

The teaching of each unit of the language course took from one to one and a half weeks. The units taught were eight in total. The students filled out the revision tests after the completion of each unit. The experimental group used the e-portfolio as a storage medium of the printed test that was scanned and saved in it and the control group used the printed portfolio of student achievements. Because the age of the students -7 years old- would be restrictive in the process of creating their personal electronic portfolios, the researcher and teacher created folders in dropbox and shared them with parents and students. Each student had his/her own portfolio. The students and their parents were able to access the folder and its content at any time.

\section{Results}

\subsection{Attitudes towards Learning ( $1^{\text {st }}$ research question)}

The first part of the questionnaire aims to investigate students' attitudes towards learning through 15 queries

The results of the survey suggest that a large percentage of students in both teams feel that education is important for themselves and this percentage remains almost identical before and after the educational intervention, with the percentages being $65 \%$ and $80 \%$ respectively in the experimental group and $70 \%$ and $80 \%$ respectively in the control group. 
Another change is noted in the percentages of the proposal "I check my assignments to correct my mistakes", which increases by $10 \%$ in both the experimental group and $10 \%$ in the control group. Initially, 17 students from both groups responded positively before the intervention and 19 students responded positively after the educational intervention in the final questionnaire.

Equally significant is the result of the sentence "I can control how successful I am". Before the educational intervention, 11 experimental group students $(55 \%)$ responded positively, while 5 students (25\%) responded negatively, and 4 students $(20 \%)$ kept a neutral attitude.

After the educational intervention, 17 students (85\%) answered positively, 1 pupil (5\%) gave a negative answer, while 2 students (10\%) remained neutral. As far as the control group is concerned, before the educational intervention, 17 students $(85 \%)$ responded positively, no student gave a negative answer, while 3 students (15\%) were neutral. After the educational intervention, 14 students (70\%) answered positively, 3 students (15\%) answered negatively and 3 students (15\%) remained neutral.

The results in the sentence "I try hard to improve my performance" is also worth mentioning, since the percentage of the experimental group students that gave positive answers remains firmly the same rating $70 \%$, both before and after the intervention. The negative responses reduced to zero while the percentage of students who kept a neutral stance on the question increased, noting a rate of $15 \%$. In the final questionnaire of the control group there has been a decrease of $5 \%$ in the rate of positive responses, which corresponds to one student, while the rate of students who kept a neutral stance increased by $10 \%$, which corresponds to 4 students. To sum up, one can assume that the students of both groups are trying very hard and are keen on improving their overall performance.

Finally, it should be taken into account that after the educational intervention there was a big difference in the answers of the experimental group in the sentence "I keep on trying even when I think what I do is not interesting" since there was a significant increase from $65 \%$ to $90 \%$ in those who answered positively and a reduction of negative responses from $25 \%$ to $5 \%$, which corresponds to 1 student. However, the control group's results noted a reduction in the rate of positive responses from $75 \%$ to $65 \%$ and an increase in the neutral attitudes from $10 \%$ to $30 \%$.

Table 1, below, lists the elements which demonstrate the differences (increases-decreases) in percentages that resulted from the responses of the participating students of the two groups in the queries of the questionnaire concerning their attitudes towards learning. 


\section{Macrothink}

Table 1. Differentiating Elements Among Students' Responses Regarding Their Attitudes

Towards Learning.

\begin{tabular}{|c|c|c|c|c|c|c|}
\hline \multirow[b]{2}{*}{ Query-Proposal } & \multicolumn{2}{|c|}{ B1 - CONTROL GROUP } & \multirow[b]{2}{*}{ 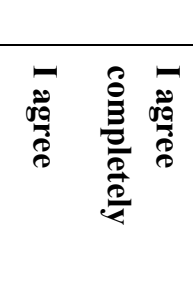 } & \multicolumn{3}{|c|}{ B2 - EXPERIMENTAL GROUP } \\
\hline & 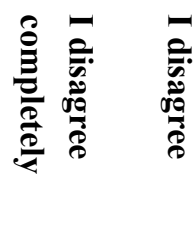 & 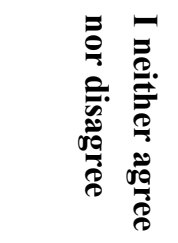 & & 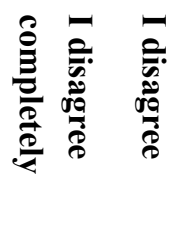 & 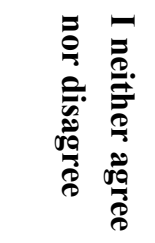 & 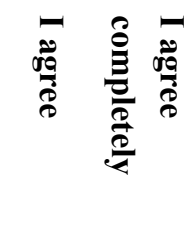 \\
\hline Education is important for me & $0 \%$ & $\begin{array}{l}\text { Decrease } \\
10 \%\end{array}$ & $\begin{array}{l}\text { Increase } \\
10 \%\end{array}$ & $\begin{array}{l}\text { Decrease } \\
10 \%\end{array}$ & $\begin{array}{l}\text { Decrease } \\
5 \%\end{array}$ & $\begin{array}{l}\text { Increase } \\
15 \%\end{array}$ \\
\hline I study on a regular basis & $\begin{array}{l}\text { Increase } \\
5 \%\end{array}$ & $\begin{array}{l}\text { Increase } \\
15 \%\end{array}$ & $\begin{array}{l}\text { Decrease } \\
20 \%\end{array}$ & $\begin{array}{l}\text { Decrease } \\
5 \%\end{array}$ & $\begin{array}{l}\text { Increase } \\
5 \%\end{array}$ & $0 \%$ \\
\hline $\begin{array}{l}\text { I check my assignments to } \\
\text { correct my mistakes }\end{array}$ & $\begin{array}{l}\text { Decrease } \\
5 \%\end{array}$ & $\begin{array}{l}\text { Decrease } \\
5 \%\end{array}$ & $\begin{array}{l}\text { Increase } \\
10 \%\end{array}$ & $\begin{array}{l}\text { Increase } \\
5 \%\end{array}$ & $\begin{array}{l}\text { Decrease } \\
10 \%\end{array}$ & $\begin{array}{l}\text { Increase } \\
10 \%\end{array}$ \\
\hline $\begin{array}{l}\text { I try hard to improve my } \\
\text { performance }\end{array}$ & $\begin{array}{l}\text { Decrease } \\
5 \%\end{array}$ & $\begin{array}{l}\text { Increase } \\
10 \%\end{array}$ & $\begin{array}{l}\text { Decrease } \\
5 \%\end{array}$ & $\begin{array}{l}\text { Decrease } \\
10 \%\end{array}$ & $\begin{array}{l}\text { Increase } \\
15 \%\end{array}$ & $\begin{array}{l}\text { Decrease } \\
5 \%\end{array}$ \\
\hline My grades are good & $\begin{array}{l}\text { Decrease } \\
5 \%\end{array}$ & $\begin{array}{l}\text { Increase } \\
5 \%\end{array}$ & $0 \%$ & $\begin{array}{l}\text { Decrease } \\
10 \%\end{array}$ & $\begin{array}{l}\text { Increase } \\
15 \%\end{array}$ & $\begin{array}{l}\text { Decrease } \\
5 \%\end{array}$ \\
\hline $\begin{array}{l}\text { I'm interested in learning in } \\
\text { every way and it is hard }\end{array}$ & $0 \%$ & $\begin{array}{l}\text { Increase } \\
5 \%\end{array}$ & $\begin{array}{l}\text { Decrease } \\
5 \%\end{array}$ & $\begin{array}{l}\text { Decrease } \\
15 \%\end{array}$ & $\begin{array}{l}\text { Increase } \\
10 \%\end{array}$ & $\begin{array}{l}\text { Increase } \\
5 \%\end{array}$ \\
\hline $\begin{array}{l}\text { I'm trying to understand the } \\
\text { content of the lesson and that } \\
\text { is very important for me }\end{array}$ & $\begin{array}{l}\text { Decrease } \\
5 \%\end{array}$ & $\begin{array}{l}\text { Increase } \\
35 \%\end{array}$ & $\begin{array}{l}\text { Decrease } 30 \\
\%\end{array}$ & $\begin{array}{l}\text { Decrease } \\
5 \%\end{array}$ & $\begin{array}{l}\text { Decrease } \\
5 \%\end{array}$ & $\begin{array}{l}\text { Increase } \\
10 \%\end{array}$ \\
\hline $\begin{array}{l}\text { Whenever I face a problem, } \\
\text { I'm trying to solve it on my } \\
\text { own }\end{array}$ & $\begin{array}{l}\text { Increase } \\
5 \%\end{array}$ & $\begin{array}{l}\text { Decrease } \\
5 \%\end{array}$ & $0 \%$ & $0 \%$ & $\begin{array}{l}\text { Increase } \\
10 \%\end{array}$ & $\begin{array}{l}\text { Decrease } \\
10 \%\end{array}$ \\
\hline $\begin{array}{l}\text { I keep on trying even if what } \\
\text { I'm doing is not interesting }\end{array}$ & $\begin{array}{l}\text { Decrease } \\
10 \%\end{array}$ & $\begin{array}{l}\text { Increase } \\
20 \%\end{array}$ & $\begin{array}{l}\text { Decrease } \\
10 \%\end{array}$ & $\begin{array}{l}\text { Decrease } \\
20 \%\end{array}$ & $\begin{array}{l}\text { Decrease } \\
5 \%\end{array}$ & $\begin{array}{l}\text { Increase } \\
25 \%\end{array}$ \\
\hline $\begin{array}{l}\text { I can control how successful I } \\
\text { am }\end{array}$ & $\begin{array}{l}\text { Increase } \\
15 \%\end{array}$ & $0 \%$ & $\begin{array}{l}\text { Decrease } \\
15 \%\end{array}$ & $\begin{array}{l}\text { Decrease } \\
20 \%\end{array}$ & $\begin{array}{l}\text { Decrease } \\
10 \%\end{array}$ & $\begin{array}{l}\text { Increase } \\
30 \%\end{array}$ \\
\hline $\begin{array}{l}\text { I do not know how to improve } \\
\text { learning }\end{array}$ & $\begin{array}{l}\text { Decrease } \\
60 \%\end{array}$ & $\begin{array}{l}\text { Increase } \\
10 \%\end{array}$ & $\begin{array}{l}\text { Increase } \\
50 \%\end{array}$ & $\begin{array}{l}\text { Decrease } \\
25 \%\end{array}$ & $0 \%$ & $\begin{array}{l}\text { Increase } \\
25 \%\end{array}$ \\
\hline $\begin{array}{l}\text { When I encounter a problem, } \\
\text { I can find the solution with } \\
\text { the right actions }\end{array}$ & $0 \%$ & $\begin{array}{l}\text { Increase } \\
5 \%\end{array}$ & $\begin{array}{l}\text { Decrease } \\
5 \%\end{array}$ & $\begin{array}{l}\text { Decrease } \\
5 \%\end{array}$ & $\begin{array}{l}\text { Increase } \\
10 \%\end{array}$ & $\begin{array}{l}\text { Decrease } \\
5 \%\end{array}$ \\
\hline $\begin{array}{l}\text { When I have a difficult lesson, } \\
\text { I study alone }\end{array}$ & $0 \%$ & $\begin{array}{l}\text { Decrease } \\
5 \%\end{array}$ & $\begin{array}{l}\text { Increase } \\
5 \%\end{array}$ & $0 \%$ & $\begin{array}{l}\text { Increase } \\
10 \%\end{array}$ & $\begin{array}{l}\text { Decrease } \\
10 \%\end{array}$ \\
\hline I understand that what I & Decrease & Increase & Decrease & Decrease & Increase & Increase \\
\hline $\begin{array}{l}\text { learn relates to my life and } \\
\text { interests }\end{array}$ & $5 \%$ & $30 \%$ & $25 \%$ & $10 \%$ & $30 \%$ & $20 \%$ \\
\hline $\begin{array}{l}\text { I know which is the best way } \\
\text { to learn }\end{array}$ & $0 \%$ & $\begin{array}{l}\text { Increase } \\
15 \%\end{array}$ & $\begin{array}{l}\text { Decrease } \\
15 \%\end{array}$ & $\begin{array}{l}\text { Decrease } \\
5 \%\end{array}$ & $\begin{array}{l}\text { Increase } \\
10 \%\end{array}$ & $\begin{array}{l}\text { Decrease } \\
5 \%\end{array}$ \\
\hline
\end{tabular}




\subsection{Attitudes Towards School and Classroom (2 ${ }^{\text {nd }}$ research question)}

This part of the questionnaire includes queries on students' attitudes towards school and the classroom in general. It consists of 11 questions about pupils' opinions and attitudes on how they deal with school and classroom life.

The results show that both the experimental and the control group, are very positive in the sentence "School helps me learn how to write well" with matching answers of a $100 \%$ rate. Regarding the results of the sentence "my teachers' evaluation, helps me understand what I have learned and what I need to know" we observe that both groups agree with the proposal at rates ranging from $75 \%$ (control group on the initial and final questionnaire) and $80 \%$ (experimental group on the initial and final questionnaire).

It is noteworthy that both teams showed an increase in the matching rates in the proposal "I expect to go well in the lessons". In the experimental group, the percentage moved up from $80 \%$ to $85 \%$ and the percentage of neutral responses remained stable at $15 \%$. In the control group, the percentage increased by 10 per cent, corresponding to 2 pupils, and the neutral answers were reduced by 1 pupil. This demonstrates the positive attitude of students towards school in general and the environment of trust in the classroom.

There was a decrease in the percentages of both teams in the sentence "I work collectively with my other classmates". In the control group the rate of positive responses decreased by $5 \%$, which corresponds to 1 student, hence moving from $60 \%$ to $55 \%$ and in the experimental group the rate decreased by $10 \%$, which corresponds to 2 students, i.e. from $70 \%$ to $60 \%$. We observed that the students in the experimental group tend to work alone in assignments of specific courses, like language and mathematics and cooperate in other subjects.

A careful observation of the results brought forth several significant differences between the two groups before and after the educational intervention in the following proposals:

"I am responsible for my school grades"

"I have the opportunity to express my opinion in the classroom"

"School helps me think about my assignments and set goals for the future"

"My schoolwork is interesting"

More specifically, in the first sentence " I am responsible for my grades at school", there is an increase of $10 \%$ in positive responses. In detail, the number of students who gave positive responses went from 14 at the beginning to 16 at the end of the intervention, reaching $80 \%$. In the control group for the same answer, we have a $25 \%$ decrease in positive responses with the number of students who agree dropping from 16 to 11 .

In the proposal, "I have the opportunity to express my point of view in the classroom", the experimental group has showed a slight increase in the agreement rate from $35 \%$ to $40 \%$. In the initial questionnaire, 7 students responded positively, moving to 8 at the end of the intervention. The results of the same sentence show a significant reduction in the control group, as the agreeing rates dropped from $70 \%$ to $50 \%$. At first 14 pupils responded 
positively, while in the final questionnaire the number of pupils dropped to 10.

The difference between the experimental group and the control group in the proposal "School helps me to think about my assignments and set goals for the future" is very important. Before the intervention, the experimental group had a percentage of $85 \%$ in positive answers and $20 \%$ in negative answers, corresponding to 17 and 4 pupils respectively. After the end of the intervention, the percentage of positive replies remained the same i.e. $85 \%$ but the rate of negative responses went down to zero and the answer " I don't know" moved up to $15 \%$. Regarding the control group, since the beginning of the intervention there were no negative answers in the initial questionnaire, the percentage of positive responses being $95 \%$ and $5 \%$ being neutral. At the end of the intervention, the rate of responding answers was reduced by $30 \%$, i.e. $65 \%$, and the percentage of neutral responses increased significantly to $40 \%$, corresponding to 12 students.

There is also a significant rate differentiation in the sentence "My schoolwork intrigues me" after the end of the educational intervention, especially in the control group. The positive responses in the initial questionnaire scored a rate of $75 \%$ in the experimental group, which is equivalent to 15 students, while at the end of the intervention the answers moved up by $10 \%$ and reached $85 \%$, meaning 17 students. It is worth noting that there were no negative answers in the final questionnaire. In the control group the positive responses to the first questionnaire scored a rate of $90 \%$, i.e. 18 students, while in the final questionnaire the percentage decreased by $20 \%$, which corresponds to 4 pupils. It is also worth mentioning that while there were no negative answers at the beginning of the intervention, there were 2 negative answers $(10 \%)$ after the end of the experiment. Furthermore, neutral responses increased from $10 \%$ to $20 \%$.

Table 2, below, shows the differences (increases-decreases) in percentages that resulted from the responses of the participating students of the two groups in the queries of the questionnaire concerning their attitudes towards learning. 
Table 2. Differentiating Elements in Students' Attitudes Towards School-Classroom

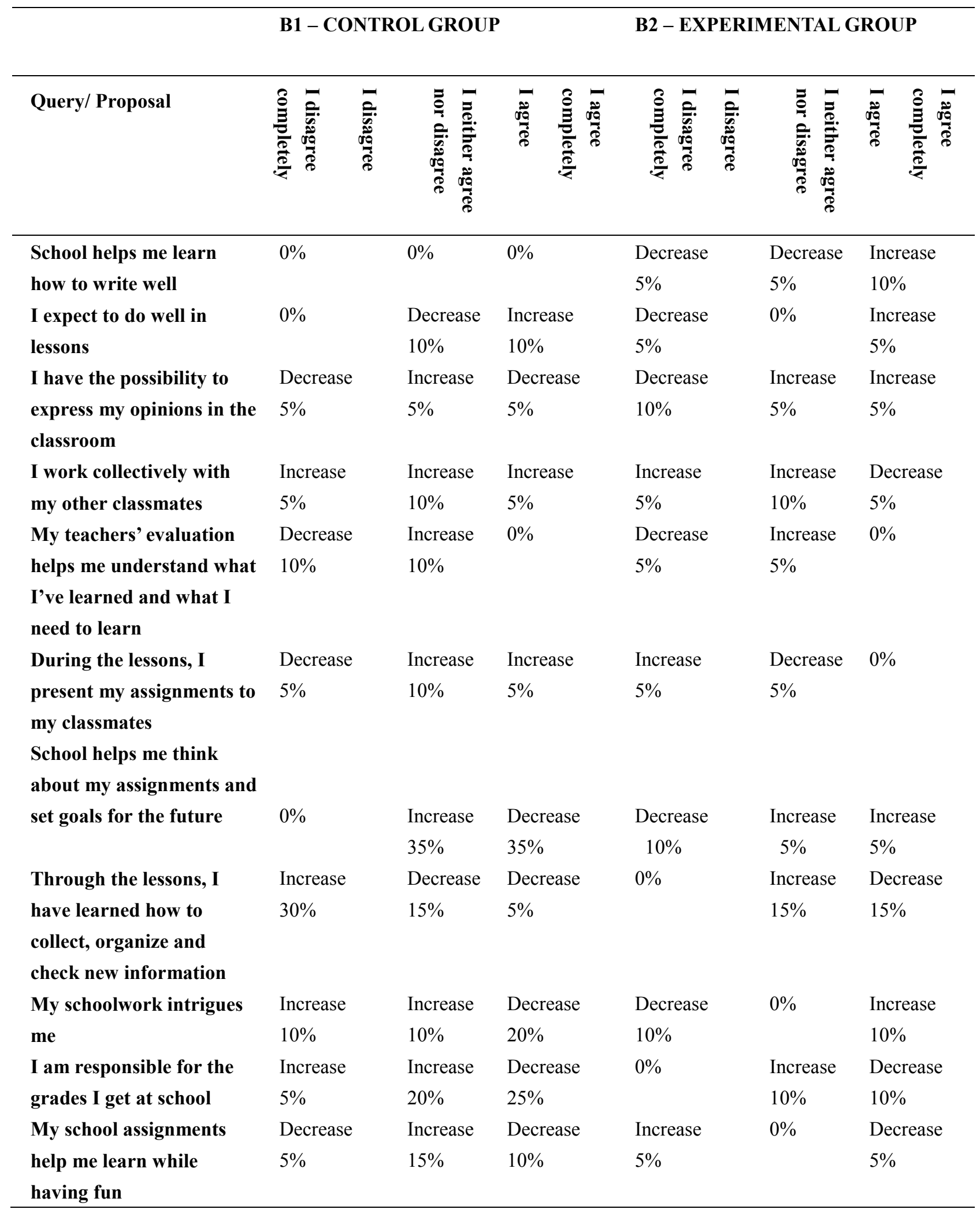


For the evaluation of the students ' statements in both sections of the questionnaire (students' attitudes regarding learning and opinions about the classroom and school life in general) and for the comparison of indicators between students of the two groups, we created two indicators, one for each group of likert questions, with the sum of values of every question in the group, where the statement [I strongly disagree] corresponds to [1], the statement [I disagree] with [2], the statement [I don't know] [3], the statement [I agree] with [4] and finally the statement [I strongly agree] with [5].

Table (3), below, presents the average scores of the indicators resulting from the students' statements in the two sections of the questionnaire per group.

Table 3. Average Scores of the Questionnaire Indicators per Group and Experimental Stage

\begin{tabular}{llllc}
\hline Group & \multicolumn{2}{c}{$\begin{array}{c}\text { Experimental } \\
\text { Group }\end{array}$} & \multicolumn{2}{c}{$\begin{array}{c}\text { Control } \\
\text { Group }\end{array}$} \\
\hline Indicators of Questionnaire Sections & Before & After & Before & After \\
$\mathbf{1}^{\text {st }}$ Questionnaire Section & 61,75 & 64,30 & 63,50 & 64,05 \\
$\mathbf{2}^{\text {nd }}$ Questionnaire Section & 46,95 & 47,45 & 48,80 & 48,90 \\
\hline
\end{tabular}

\subsection{Development of self-assessment skills by students ( $3^{\text {rd }}$ research question)}

Through observation of the differences between the students' evaluation and the teacher's feedback in the assessment rubrics, we attempt to investigate the contribution of the e-portfolio in the development of students ' self-evaluation skills. In order to compare the rubrics' results of students and teachers we created an equal number of variables for each measurement table, the values of which are based on the recorded statements, grading with one [1] [Good], two [2] [Very Good] and with three [3] [Excellent].

The comparison of differentiations in the averages of the teacher's and the students' statements were made with t-test statistical criteria for independent samples (for variables that follow a normal distribution) and Mann-Witney criteria (for the rest of the variables). From the observation of the descriptive data it stems out that, in all cases, the students rated their performance higher than their teacher. Indicatively, the smallest difference in ratings was recorded in the third measurement $(-7.27 \%, \mathrm{t}(38)=-2.541, \mathrm{~ns})$ and the largest in the seventh $(-39.87 \%, \mathrm{t}(38)=-5,456, \mathrm{p}=, 000)$. 
Table 4. Differentiation in Ratings between Teacher and Student Rubric Results

\begin{tabular}{|c|c|c|c|c|c|c|c|}
\hline \multicolumn{2}{|c|}{ Measurement Evaluator } & \multirow{2}{*}{ (w) } & \multirow{2}{*}{$\begin{array}{l}\text { Sd } \\
2,477\end{array}$} & \multirow{2}{*}{$\begin{array}{l}\% \text { diff } \\
-30,08\end{array}$} & \multirow{2}{*}{$\begin{array}{l}\mathbf{t} \\
-2,015^{*}\end{array}$} & \multirow{2}{*}{$\begin{array}{l}\text { df } \\
38\end{array}$} & \multirow{2}{*}{$\begin{array}{l}\mathbf{p} \\
, 044\end{array}$} \\
\hline $1^{\text {st }}$ & Teacher & & & & & & \\
\hline measurement & Student & 8,65 & 1,309 & & & & \\
\hline $2^{\text {nd }}$ & Teacher & 11,65 & 3,329 & $-17,60$ & $-2,333^{*}$ & 38 &, 020 \\
\hline measurement & Student & 13,70 & 2,473 & & & & \\
\hline $3^{\text {rd }}$ & Teacher & 19,95 & 2,819 & $-7,27$ & $-2,541$ & 38 & ns \\
\hline measurement & Student & 21,40 & 2,210 & & & & \\
\hline $4^{\text {th }}$ & Teacher & 9,60 & 2,303 & $-16,15$ & $-2,195^{*}$ & 38 & ,028 \\
\hline measurement & Student & 11,15 & 1,461 & & & & \\
\hline $5^{\text {th }}$ & Teacher & 14,65 & 2,540 & $-11,26$ & $-2,117$ & 38 & 041 \\
\hline measurement & Student & 16,30 & 2,386 & & & & \\
\hline $6^{\text {th }}$ & Teacher & 6,60 & 1,729 & $-24,24$ & $-3,532$ & 38 & 001 \\
\hline measurement & Student & 8,20 & 1,056 & & & & \\
\hline $7^{\text {th }}$ & Teacher & 7,65 & 2,159 & $-39,87$ & $-5,456$ & 38 &, 000 \\
\hline measurement & Student & 10,70 & 1,261 & & & & \\
\hline $8^{\text {th }}$ & Teacher & 10,05 & 1,791 & $-10,95$ & $-1,975$ & 38 & 048 \\
\hline measurement & Student & 11,15 & 1,663 & & & & \\
\hline
\end{tabular}

* In cases where the values of the variables did not follow the normal distribution, we used the non-parametric Mann-Witney criterion instead of applying the t-test for independent samples.

Table 5, below, shows the averages of student's self-assessments and their teacher's evaluation.

Table 5. Average Scores of Students' Self-Assessments and Their Teacher's Evaluation in 8 Rubrics

\begin{tabular}{llll}
\hline Measurement & Evaluator & $(\boldsymbol{\cdots}$ & Sd \\
\hline 1st $^{2}$ measurement & Teacher & 6,65 & 2,477 \\
& Student & 8,65 & 1,309 \\
$\mathbf{2}^{\text {nd }}$ measurement & Teacher & 11,65 & 3,329 \\
& Student & 13,70 & 2,473 \\
$\mathbf{3}^{\text {rd }}$ measurement & Teacher & 19,95 & 2,819 \\
& Student & 21,40 & 2,210 \\
$\mathbf{4}^{\text {th }}$ measurement & Teacher & 9,60 & 2,303 \\
& Student & 11,15 & 1,461 \\
$\mathbf{5}^{\text {th }}$ measurement & Teacher & 14,65 & 2,540 \\
& Student & 16,30 & 2,386 \\
$\mathbf{6}^{\text {th }}$ measurement & Teacher & 6,60 & 1,729 \\
& Student & 8,20 & 1,056 \\
$\mathbf{7}^{\text {th }}$ measurement & Teacher & 7,65 & 2,159 \\
\multirow{2}{*}{$\mathbf{8}^{\text {th }}$ measurement } & Student & 10,70 & 1,261 \\
& Teacher & 10,05 & 1,791 \\
& Student & 11,15 & 1,663 \\
\hline
\end{tabular}

\section{Discussion}

Regarding the first research question, which investigates the contribution of e-portfolio in the development of students ' attitudes towards learning, the results gathered from the 
questionnaires of both groups present differences between the initial and final percentages. The experimental group presents an increase of $2,55 \%$ in positive replies at the end of the educational intervention and the control group presents an increase of $0.55 \%$. It should be noted that the results of the comparison are not statistically significant.

In detail, from 15 proposals given to students of the experimental and control group, about their attitudes on learning, we observe that in 2 sentences: "Education is important for me," and "I check my assignments to correct my mistakes" increase rates remain stable and identical.

In the question, "I study my lessons regularly," the increase rates remain constant in the experimental group, while the control group has a significant reduction in rates.

Also, there is a significant reduction in the rates of the control group in the 5 following suggestions. In the same proposals, the experimental group presents a significant increase in rates except for the last proposal, in which there is a slight decrease. "I'm trying to understand the content of the lesson and that is very important for me"

"I'm trying to understand the content of the lesson and that is very important for me"

"I can control how successful I am"

"I understand that what I learn relates to my life and interests"

"I know which is the best way to learn".

In the six suggestions that follow, there are no significant differences in the percentages of both the experimental group and the control group:

"I'm trying very hard to improve my performance"

"My grades are good"

"I'm interested in learning in every way and it is hard"

"Whenever I face a problem, I'm trying to solve it on my own"

"When I encounter a problem, I can find the solution with the right actions" "When I have a difficult lesson, I study alone".

By bringing together all these elements we observe that from 15 research proposals there was no significant change in eight proposals neither in the control group nor in the experimental group, while there was a change in the experimental group in 5 out of the 15 proposals. The control group's results were different in 5 sentences, which noted decrease.

From the above results, there is a slight change in the experimental group students' attitudes towards school due to their use of the e-portfolio. From the findings it appears that the experimental group and the control group present a more positive attitude after the end of the intervention, with the experimental group, which used the e-portfolio, to score a greater percentage of positive responses. 
This finding is in accordance with results from the bibliography. According to Vavrous (1990) and Torrance (1995) (in Andreadakis, 2006) authentic assessment is a systematic process whereby the teacher collects and documents evident of a student's progress through the active participation in the context of teaching - learning. The authentic assessment promotes the holistic perception of the world through everyday situations, to ensure the active participation of the learner, the ability to form opinions and participate in the selection of activities and evaluation. Therefore, authentic assessment is primarily an authentic form of learning and secondarily of assessment.

In relation to the second research question, which investigates the e-portfolio's contribution in shaping more positive attitudes of students towards school, the results gathered from the questionnaires and the two groups, both the experimental and the control group, there are differences between the initial and final percentages. The experimental group presents an increase of $0,47 \%$ in positive replies at the end of the educational intervention and the control group presents an increase of $0.1 \%$. It should be noted that the results of the comparison are not statistically significant.

More specifically, from the 11 queries for this section of the questionnaire, we observe that in 2 of them there are not significant changes, neither in the experimental group nor in the control group, since the rates do not show any significant change. The proposals are:

"During the lessons, I present my assignments to my classmates"

"My school assignments help me learn while having fun".

In the proposal "I work collectively with my other classmates", there was a decrease in both the experimental and the control group rates. The proposals: "School helps me learn how to write well», «I have the ability to express my opinion in the classroom", "School helps me think about my assignments and set goals for the future», "My schoolwork intrigues me", "I am responsible for the grades I get at school», there was a positive change in the experimental group but not in the control group.

The summary for this specific research question, where 11 proposals investigate the possibility to develop a more positive attitude towards school life using the e-portfolio, we observe a significant change of positive responses in 5 proposals for the experimental group. In this section's 11 proposals, the control team had a small percentage of positive responses in 2 proposals, while there was a significant decrease in 7 proposals.

From the above results, there is a slight differentiation in the experimental group students' attitudes towards school owing to their use of the e-portfolio.

From the findings it appears that the experimental group and the control group present a more positive attitude after the end of the intervention, with the experimental group, which used the e-portfolio, to score a greater percentage of positive responses.

The result is in accordance with the relevant literature according to which authentic assessment (Vygotsky, 1988), assesses the abilities of the students during their interaction with the teacher, classmates and the school environment, involving them in the process of 
self-assessment and external assessment, leading them to take responsibility for their learning.

As to the research question investigating the contribution of the e-portfolio on the development of students' self-evaluation skills, we have used the information gathered from the analysis of the differences in the students' and teacher's assessment rubrics.

From the observation of the descriptive data it stems out that, in all cases, the students rated their performance higher than their teacher. Indicatively, the smallest difference in ratings was recorded in the third measurement $(-7.27 \%, \mathrm{t}(38)=-2.541, \mathrm{~ns})$ and the largest in the seventh measurement $(-39.87 \%, \mathrm{t}(38)=-5,456, \mathrm{p}=, 000)$.

According to the data obtained from the analysis, the students rated their performance higher than the teacher in all 8 measurements. From this finding we see that the student's electronic portfolio allows the teacher to monitor, evaluate and direct the progress of each student and to think seriously about the effectiveness of teaching. A well-organized student achievement folder becomes a good tool for formative evaluation (Georgoussis, 1999).

\section{Conclusions}

Based on the findings of this research and the above analysis we can draw the following conclusions:

With regard to the contribution of electronic portfolio, in the shaping of a more positive attitude of the students towards learning, it occurs that the experimental group is positive about it. The majority of students believe that the e-portfolio helps them to deal with learning with more positive emotions. E-portfolio is a powerful tool in the hands of small students and their involvement in the creation of the digital portfolio encourages them and provides them with incentives to participate in the learning process.

On the contribution of the e-portfolio in the development of more positive attitudes towards school and the classroom, we observe that the experimental group is positive as the majority considers that it helps them improve their relations with the in-class environment and the school. The involvement of technology, for creating the e-portfolio makes learning more interesting as it involves students in productive work promoting their creativity.

Concerning the contribution of the e-portfolio to the acquisition of student self-assessment skills, it appears that it helps strengthen their self-confidence and improve the student's self-image.

This paper also involves some noteworthy limitations. As far as the sample of the survey is concerned, there were pupils of the second grade of primary school and consisted of 40 people. The electronic portfolio only contained evaluations in the language lesson. There has been a time constraint on the implementation of the specific intervention and therefore the conclusions drawn are not considered completely objective and safe. Therefore, a future conduction this or a similar research could be held in the duration of the entire school year, in 
all school subjects and in all classes of primary school.

Another future direction that could be implemented in a future research would be to create e-portfolios in all classes of primary school starting from the first, to determine the contribution of the e-portfolio in the assessment and development of metacognitive skills. It is also important to investigate the reasons why the student e-portfolio is not by teachers in Greek primary education.

Finally, each research question of this paper could be a separate research which could lead to more safe and valid results if conducted to a larger sample and for more time.

\section{References}

Andreadakis, N. (2006). Portfolio-based Assessment [University Notes]. University of Crete, Department of Primary Education, Academic year 2005-2006. Rethymno.

Barrett, H. C. (2000). Researching electronic portfolios and learner engagement: The REFLECT initiative. Journal of Adolescent \& Adult Literacy, 50(6), 436-449. https://doi.org/10.1598/JAAL.50.6.2

Barrett, H., \& Knezek, D. (2003). E-portfolios: Issues in assessment, accountability and preservice teacher preparation. Retrieve February 4, 2018 from https://eric.ed.gov/?id=ED476185

Beresford, W., \& Cobham, D. (2011). Undergraduate students: Interactive, online experiences and eportfolio development. In International Conference on Information and Education Technology (ICIET). https://doi.org/10.1109/ICCSN.2011.6013825

Brown, D. (1998). New Ways of Classroom Assessment, revised. TESOL Press.

Callison, D. (1998). Authentic Assessment. School Library Media Activities Monthly, 14(5), 42-43.

Coutinho, C., \& Bottentuit, J. (2008). The use of Web 2.0 tools to develop e-portfolios in a teacher training program: An exploratory survey. Retrieved February 5, 2018 from https://repositorium.sdum.uminho.pt/bitstream/1822/8554/1/icetpdf.pdf

Fotopoulou, C. (2012). E-portfolio as an educational tool in Secondary Education (Master's Thesis). Piraeus: University of Piraeus.

Gaytan, J., \& McEwen, B. (2009). Effective online instructional and assessment strategies. The American Journal of Distance Education, 21(3), 117-132. https://doi.org/10.1080/08923640701341653

Georgoussis, P. (1999). Measurement and Assessment of Student Performance. Athens: Self-publishing.

Hallam, C., \& Creagh, T. (2010). ePortfolio use by university students in Australia: A review of the Australian ePortfolio Project. Higher Education Research and Development, 29(2), 
179-193. https://doi.org/10.1080/07294360903510582

Hendrickson, K. (2012). Assessment in Finland: A Scholarly Reflection on One Country's Use of Formative, Summative, and Evaluation Practices. Mid-Western Educational Researcher, 25(1/2), 33-43.

Hsieh, L., \& Chen (2015). Students' Perspectives on Eportfolio Development and Implementation: A Case Study in Taiwanese Higher Education. Australasian Journal of Educational Technology, 31(6), 641-656. https://doi.org/10.14742/ajet.1605

Klampfer, A., \& Köhler, T. (2013). ePortfolios@Teacher Training: An Evaluation of Technological and Motivational Factors. Paper presented at the International Association for Development of the Information Society (IADIS) International Conference on e-Learning, 126-134.

Knight, E., Hakel, D., \& Gromko, M. (2006). The Relationship between Electronic Portfolio Participation and Student Success. Retrieved February 15, 2018 from https://eric.ed.gov/?id=ED493824

Landis, M., Scott, S., \& Kahn, S. (2015). Examining the Role of Reflection in ePortfolios: A Case Study. International Journal of ePortfolio, 5(2), 107-121.

Mason, R., \& Williams, B. (2016). Using ePortfolio's to Assess Undergraduate Paramedic Students: A Proof of Concept Evaluation. International Journal of Higher Education, 5(3), 146-154. https://doi.org/10.5430/ijhe.v5n3p146

McWhorter, R., Delello, J., Roberts, P., Raisor, C., \& Fowler, D. (2013). A cross-case analysis of the use of web-based eportfolios in higher education. Journal of Information Technology Education: Innovations in Practice, 12, 253-286. https://doi.org/10.28945/1900

Meyer, C. (1992). What is the difference between authentic and performance assessment? Educational Leadership, 49, 39-40.

MOSEP - More Self-Esteem with My E-portfolio (2007). Grab your future with an e-portfolio! Retrieved $\quad$ February $13, \quad 2018$ from http://www.cel.agh.edu.pl/wp-content/uploads/2009/11/mosep_study.pdf

Nor Azlan M., Amin E., \& Mohd, N. (2015). Are Students Ready to Adopt Eportfolio? Social Science and Humanities Context. Asian Social Science, 11(13), 269-275.

Papathanasiou, G., \& Manousou, E. (2011). The Student Electronic Portfolio (SAP) as a tool for implementing complementary distance learning school education. Retrieved January 26 , 2018 from https://eproceedings.epublishing.ekt.gr/index.php/openedu/article/view/720

Paris, S., \& Ayres, L. (1994). Becoming Reflective Students and Teachers with Portfolios and Authentic Assessment. Washington, DC US: American Psychological Association. https://doi.org/10.1037/10158-000 


\section{Macrothink}

International Journal of Education ISSN 1948-5476 2019, Vol. 11, No. 1

Parker, M., Ndoye, A., \& Ritzhaupt, A. (2012). Qualitative Analysis of Student Perceptions of Eportfolios in a Teacher Education Program. Journal of Digital Learning in Teacher Education, 28(3), 99-107. https://doi.org/10.1080/21532974.2012.10784687

Paroutsas, D. (2011). The Student Worksheet/Portfolio as a means of authentic assessment in Primary Education (Master's Thesis). Patras: Greek Open University.

Reкаlidou, G., Zantali, Th., \& Sofianidou, M. (2010). The evaluation in Kindergarten. Pilot implementation of an Evaluation Project and Self-Assessment based on the Portfolio. $\begin{array}{llll}\text { Retrieved January } & 19, & & \\ & \text { J } & & \end{array}$ http://www.pi-schools.gr/download/publications/epitheorisi/teyxos16/022-038.pdf

Ritzhaupt, A., Singh, O., \& Seyferth, T. (2008). Development of the electronic portfolio student perspective: an e-portfolio integration initiative. Journal of Computing in Higher Education, 19(2), 47-71. https://doi.org/10.1007/bf03033426

Segers, M. S. R. (1999). Assessment in student - centered education: does it make a difference? Uniscene Newsletter, 2, 6-9.

Stylianou, M. (2013). E-portfolio Assessment (Master's Thesis). Nicosia: Open University of Cyprus.

Tsagari, D. (2011). Investigating the 'assessment literacy' of EFL state school teachers in Greece. In D. Tsagari, \& amp; Csépes, I. (Eds.), Classroom-based language assessment (pp.169-190). Frankfurt am Main: Peter Lang.

Tsoutsou, D., \& Bertsou, S. (2013). An Experimental Study on the Utilization of the E-Portfolio in Primary Education. Retrieved January 13, 2018 from https://e-portfoliogr.weebly.com/uploads/2/1/0/4/21044446/dt_sm_e-portfolios.pdf

Varsamidou, A., \& Res, G. (2007). Authentic assessment/ dossier/portfolio assessment: A dynamic \& flexible evaluation proposal in compulsory education. Retrieved January 20, 2018

from https://eclass.gunet.gr/modules/document/file.php/NETGU200/ $\xi_{10 \lambda o ́} \gamma \eta \sigma \eta \% 20-\% 20 \varphi \alpha ́$ $\kappa \varepsilon \lambda \circ \varsigma_{0} 20 \alpha \xi 10 \lambda \gamma_{\gamma \eta} \sigma \eta \varsigma . p d f$

Vygotsky, L. (1988). Thought \& Language. (A. Rodi, Trans.). Athens: Gnosi.

Wuetherick, B., \& Dickinson, J. (2015). Why eportfolios? Student Perceptions of ePortfolio Use in Continuing Education Learning Environments. International Journal of ePortfolio, 5(1), 39-53. 


\section{Macrothink}

\section{Copyright Disclaimer}

Copyright for this article is retained by the author(s), with first publication rights granted to the journal.

This is an open-access article distributed under the terms and conditions of the Creative Commons Attribution license (http://creativecommons.org/licenses/by/3.0/). 